\title{
Myocardial Recovery Following Left Ventricular Assist Device Therapy
}

\author{
M. Navaratnarajah, M. Ibrahim, M. Yacoub and C. Terracciano \\ Heart Science Centre, Imperial College London, Harefield Hospital \\ United Kingdom
}

\section{Introduction}

Heart Failure (HF) represents an increasing clinical problem with a reported mortality (for either diastolic or systolic HF) of approximately $60 \%$ at 5 years after diagnosis (Shahar et al. 2004). The incidence of end-stage HF has increased four-fold in the last 20 years (Hubler et al. 2003; Terracciano et al. 2010). Symptomatic HF confers a worse prognosis than the majority of cancers, with mortality as high as $45 \%$ at one year (Cohn 1996; Jessup and Brozena 2003), and there are currently more than 16 million people in Europe and the United States (US) suffering from this disease. HF is also a major burden in the developing world (Mayosi 2007). Despite substantial medical advances in the treatment of HF, cardiac transplantation (CTx) remains the best long term therapy for patients suffering from endstage disease, with $50 \%$ survival at 10 years post CTx (Hunt, SA et al. 2009a; Trulock et al. 2007). A fixed and inadequate donor organ pool means that CTx is available to only a small proportion of eligible patients. In the US an estimated 100000 patients are believed to be suitable for CTx (Maybaum et al. 2008), but only 2200 transplants are performed annually (Hunt,SA et al. 2009b). As a consequence the use of LVADs as Bridge-to-Transplantation (BTT) has increased steadily over the last few years and approximately 9000 CTx candidates, i.e. more than a third of all listed candidates in the US, have undergone LVAD implantation since 1999 (Mancini and Lietz 2010).

Initially, LVADs were utilised in the acute setting, in the management of post-cardiotomy cardiogenic shock (PCCS), a rare clinical scenario associated with high morbidity and mortality (Mehta et al. 1996). Despite improvements in LVAD technology, and the understanding of PCCS, the use of mechanical unloading (MU) in this acute setting is now minimal, with large studies showing survival of 23-52.4\% (Sylvin et al. 2010).

The role of LVADs subsequently expanded to incorporate patients with severe drugresistant HF, primarily as a BTT, with subsequent extension of the role to include "destination therapy" (DT) in those patients unsuitable for CTx (Kirklin et al. 2011).

In a small minority of patients a third application for chronic LVAD therapy, "Bridge-toRecovery" (BTR) evolved, following the observation that MU appeared to coincide with cellular, molecular, electrophysiological and structural myocardial changes consistent with functional recovery (Altemose et al. 1997; Farrar et al. 2002; Heerdt,PM et al. 2000a; Hetzer et al. 2000; Ogletree-Hughes et al. 2001; Sylvin et al. 2010; Young 2001). Such observations allied with anecdotal examples of cardiac recovery in isolated patients following enforced device removal (mandated by the development of complications) (Frazier 1994; Frazier and 
Myers 1999), alerted the world to the possibility that the remodelling of end-stage HF was reversible ("reverse remodelling") (Klotz et al. 2008).

Within the context of an increasing incidence of HF, amongst a growing population of older patients (> $65 \mathrm{yrs}$ ) ineligible to receive $\mathrm{CTx}$, inadequate organ availability and ever improving pump technology, the concept of BTR offers great hope as a potential treatment strategy to either replace, or work alongside that of CTx in years to come. However, BTR i.e. sufficient recovery of cardiac function to allow explantation of device, remains a controversial subject, with few successful reported cases worldwide(Birks et al. 2006; Birks et al. 2011; Maybaum et al. 2007). The Harefield protocol, a novel strategy in which LVAD is combined with pharmacotherapy including the $\beta_{2}$-AR agonist Clenbuterol, significantly increases the rate of explantation (Birks et al., 2006;Birks et al., 2011; see section 6 of this Chapter). In general, explantation rates vary considerably between studies but, with the exception of the Harefield protocol, remain universally low within the context of chronic HF (Dandel et al. 2005; Simon et al. 2005).

The purpose of this chapter is to review the effects of LVAD therapy, focussing on the mechanisms mediating functional recovery. We review clinical and experimental data supporting and opposing the concept of BTR. The first section of this chapter will focus on myocardial reverse remodelling followed by the clinical aspects of BTR.

\section{Myocardial reverse remodelling}

Myocardial remodelling associated with LVAD therapy is known to occur at structural, whole heart, cellular, molecular, metabolic, electrophysiological, cell survival and functional levels.

\subsection{LVAD induced reverse structural remodelling}

\subsubsection{Restoration of cardiac geometry and regression of myocyte hypertrophy}

LVAD therapy has been shown to reduce left ventricular dimensions (Frazier et al. 1996) and to restore the end-diastolic-pressure volume relationships (EDPVR) towards normal values (Levin et al. 1995). In addition, regression of both cardiac and myocyte hypertrophy has been consistently demonstrated to occur during LVAD treatment (Madigan et al. 2001; Zafeiridis et al. 1998).

Pharmacotherapy alone has proved effective in retarding the negative remodelling associated with HF (Yancy et al. 2001), but is unable to induce profound reverse remodelling to the extent of LVAD therapy (Levin et al. 1995). The structural changes described have not been documented in the right ventricle (RV) of LVAD supported patients, suggesting that the predominant factor driving remodelling to be haemodynamic (Klotz et al. 2008), rather than the normalization of neurohumoral and cytokine environment known to occur during support (Birks et al. 2001; Delgado, III et al. 1998; Klotz et al. 2009; McCarthy et al. 1995).

\subsubsection{Cytoskeletal proteins}

Sarcomeric and skeletal protein changes have been consistently shown to occur in association with MU. De Jonge et al. demonstrated improvements in distorted cytoskeletal architecture involving a number of proteins including actin, tropomyosin, troponin $\mathrm{T}$ and troponin C (De et al. 2002). Reversal of disruption of the amino terminus of dystrophin (Vatta et al. 2004), and upregulation of dystrophin gene expression (Mohapatra et al. 2010) occur in LVAD supported patients. Work conducted at Harefield hospital demonstrated a 
specific collection of protein expression alterations that coincided with functional recovery and device explantation, involving a variety of proteins such as myosin heavy chain, sarcomeric actin, troponin C, troponin T, lamin A/C , spectrin, integrins beta1, beta6, alphatropomyosin, alpha1-actinin, and vinculin (Birks et al. 2005; Latif et al. 2007).

\subsubsection{Extracellular matrix}

The ECM constitutes approximately $3 \%$ of normal myocardium, and is largely made up of collagen. Type 1 collagen, type 1: type 3 collagen ratio, collagen cross linking and fibrosis have been shown to be elevated in a variety of clinical as well as experimental disease states (Avendano et al. 1999; Badenhorst et al. 2003; Marijianowski et al. 1995; Mukherjee and Sen 1991; Porter and Turner 2009; Woodiwiss et al. 2001).

Reports of LVAD-induced ECM changes have been conflicting, with some revealing increased myocardial fibrosis and ECM volume following unloading (Klotz, S. et al. 2005b; Li et al. 2001; Matsumiya et al. 2005; Saito et al. 2010), and others showing a reduction (Akgul et al. 2004; Bruckner et al. 2001; Maybaum et al. 2007; Thohan et al. 2005; Thompson et al. 2005). Bruggink et al. demonstrated a biphasic response with initial expansion of ECM and then a subsequent regression with prolonged MU (Bruggink et al. 2006). This discrepancy is thought to arise from differences in HF aetiology, duration of MU, pharmacotherapy employed during MU (Klotz,S et al. 2007a), as well as the varying and often semi-quantitative methods utilised for analysis (Bruckner et al. 2000).

Matrix metalloproteinases (MMPs) are a group of enzymes responsible for collagen degradation and are tightly regulated by tissue inhibitors of metalloproteinases (TIMPs). HF is associated with large changes in MMP and TIMP action and thus ECM composition (Li et al. 2001; Matsumiya et al. 2005), and it is understood that altered regulation in their expression contributes to "negative" ECM remodelling in HF (Mann and Spinale 1998; Spinale et al. 2000; Wilson and Spinale 2001). Normalisation (decrease) of MMP1:TIMP1 ratio has been reported with LVAD use in a DCM population and coincides with increased LV collagen cross linking, type 1: type 3 ratio and increased ventricular stiffness (Klotz,S et al. 2005b). A study conducted at Harefield hospital showed that all but one (TIMP4) of the MMPs and TIMPs studied, displayed a change in expression during LVAD therapy (Felkin et al. 2009). TIMP4 expression decreased in this study in contrast to previous studies showing unchanged/decreased MMP and augmented TIMP levels to coincide with LVAD support (Klotz,S et al. 2005b; Li et al. 2001). Levels of cardiac fibrosis (Matsumiya et al. 2005; Saito et al. 2010) and profibrotic marker gene expression (Felkin et al. 2009) at time of LVAD implantation demonstrate predictive power with regards to likelihood of subsequent functional recovery, device explantability and durability of recovery. Negative ECM remodelling may represent a potentially important modifiable barrier to recovery in HF patients (Klotz, S. et al., 2007b).

Pharmacological blockade of the Renin-Angiotensin-Aldosterone-System (RAAS) in HF therapy is known to decrease cardiac fibrosis, collagen content and ventricular dilatation, with significant improvements in mortality (Arnold et al. 2003). Similar effects on ECM have also been seen in several different experimental models of HF (Bartha et al. 2008; Ibrahim et al. 2009; Meng et al. 2009). Klotz et al. have shown that ACE inhibition (ACE-I) reduces the increase in LV myocardial Angiotensin II/noradrenaline (NA) (Klotz et al. 2009), total collagen levels and collagen crosslinking associated with LVAD therapy, leading to their suggestion that pharmacological manipulation of the ECM represents a critical target in improving the frequency and extent of recovery during LVAD therapy (Klotz, S. et al. 2007b). 
No changes in RV chamber size, mass or collagen content were noted despite normalisation of MMP:TIMP ratio and myocardial Ang II levels, inferring that neither haemodynamic unloading nor pharmacotherapy alone were sufficient for positive structural ECM remodelling to occur, and that complex dual regulation (neurohumoral and haemodynamic) of fibrotic mechanisms is likely to exist. All patients were bridged to CTx in this retrospective study and hence the impact of these structural ECM changes on whole heart cardiac functional recovery was not assessed.

\subsection{LVAD effects on $\mathrm{Ca}^{2+}$ regulation and signaling pathways 2.2.1 $\mathrm{Ca}^{2+}$ regulation}

$\mathrm{HF}$ is associated with alterations in a multitude of $\mathrm{Ca}^{2+}$ regulatory mechanisms, the balance of which varies with stage and aetiology of disease (Bers 2006). Mishandling of cytoplasmic $\mathrm{Ca}^{2+}$ causes deranged myocyte excitation-contraction (EC) coupling, abnormal systolic and diastolic function, as well as arrythmogenesis in clinical and experimental HF (Gwathmey et al. 1987; Pieske et al. 1996). LVAD therapy is associated with reversal or alteration in expression and function, of many $\mathrm{Ca}^{2+}$ handling elements known to be adversely remodelled during HF, with a clear correlation with functional recovery being observed with certain parameters. Despite this, the true functional relevance of many of the LVAD- associated changes in $\mathrm{Ca}^{2+}$ cycling remains unclear.

Reverse electrophysiological remodelling occurs during LVAD therapy, demonstrated by reduction of QT interval and myocyte action potential duration (APD) (Harding et al. 2001). Mechanisms regulating APD involve alteration in function and expression of ion transporters with changes in depolarising and hyperpolarising currents. Detrimental effects of APD prolongation in HF on EC coupling, cellular relaxation and contraction are recognized (Gaughan et al. 1999; Wickenden et al. 1998), as well as positive effects such as augmentation of intracellular $\mathrm{Ca}^{2+}$ via alteration in L-type $\mathrm{Ca}^{2+}$ and NCX currents, presumed to be compensatory adaptive mechanisms (Bouchard et al. 1995; Weber et al. 2002; Wickenden et al. 1998). APD reduction has been associated with functional clinical recovery during LVAD support (Terracciano et al. 2004), but delineation of a precise contributory role of APD to functional recovery is difficult as the specific role of APD changes in HF itself remains unclear.

\subsubsection{Sarcoplasmic reticulum $\mathrm{Ca}^{2+}$ content}

A key determinant of effective $\mathrm{Ca}^{2+}$ release and myocyte contractility is the sarcoplasmic reticulum (SR) $\mathrm{Ca}^{2+}$ content and this parameter has been shown to be decreased in HF (Bers 2006) although increased SR $\mathrm{Ca}^{2+}$ content is noted to occur in some models during compensated HF (Soppa et al. 2008). 3 main mechanisms are thought to be responsible for the diminished SR $\mathrm{Ca}^{2+}$ content in HF : a) depressed Serca 2a function b) enhanced NCX function and c) enhanced SR Ca${ }^{2+}$ leak (Bers 2006). Increased SR $\mathrm{Ca}^{2+}$ uptake has been shown to occur in response to LVAD support (Dipla et al. 1998; Frazier et al. 1996), and together with augmented $\mathrm{Ca}^{2+}$ transient amplitude correlate with improved myocyte contractility (Chaudhary et al. 2004; Dipla et al. 1998). Importantly, recovery of diminished SR Ca ${ }^{2+}$ content and L-type fast inactivation (most likely secondary to increased SR $\mathrm{Ca}^{2+}$ release) correlated with myocardial recovery and device explantation (Terracciano et al. 2004).

\subsubsection{Serca 2a}

Sarcoplasmic Endoreticulum $\mathrm{Ca}^{2+}$ ATPase 2a (SERCA 2a) is the principal protein responsible for the reuptake of $\mathrm{Ca}^{2+}$ into the SR, which allows for sufficient replenishing of $\mathrm{Ca}^{2+}$ stores 
for the subsequent heartbeat. Effects on Serca 2a gene expression and protein levels vary. Clinical and experimental studies have shown recovery (Takaseya et al. 2004), as well as no change (Chaudhary et al. 2004) to occur with MU, in addition to a biphasic response, i.e. initial recovery followed by subsequent decline coinciding with contractile function deterioration (Oriyanhan et al. 2007). Similarly, phospholamban (PLB) PLB:Serca2a ratio a key determinant of contractile function (Koss et al. 1997), known to be elevated in HF, displays a similar short term recovery (decreased ratio), with later resurgence of ratio coinciding with prolonged support and decline in contractile function (Ogletree et al. 2010).

\subsection{4 $\mathrm{Na}^{+}-\mathrm{Ca}^{2+}$ exchanger (NCX)}

Enhanced NCX activity / gene expression and protein levels are known to occur in most but not all models of HF (Bers 2006) with certain studies showing no change(Hasenfuss et al. 1999; Komuro et al. 1992) or even a reduction (Heerdt,PM et al. 2000b). In an environment of high intracellular $\mathrm{Na}^{+}$, prolonged APD and diminished $\mathrm{Ca}^{2+}$ transients, enhanced $\mathrm{NCX}$ activity promotes $\mathrm{Ca}^{2+}$ entry, a probable inotropic action. Reported LVAD-induced NCX changes are equivocal, improved $\mathrm{Ca}^{2+}$ extrusion has been associated with increased NCX gene expression and functional recovery (Terracciano et al. 2007). However, partial restoration of positive force frequency relationship (FFR) (Chaudhary et al. 2004), as well as enhanced contractile strength in non-recovered patients (Heerdt,PM et al. 2000a), occurs in the absence of alterations in NCX protein levels. The well documented discordance between gene expression and protein levels, as well as regional LV expression heterogeneity, may be responsible for such discrepancies.

\subsubsection{Ryanodine receptor (RyR)}

Diastolic $\mathrm{Ca}^{2+}$ leak secondary to deranged RyR function is also an important contributor in $\mathrm{Ca}^{2+}$ mishandling in HF(Marx et al. 2000). Chronic PKA mediated hyperphosphorylation of RyR2 promoting a "leaky" receptor is just one of the proposed mechanisms thought to lead to SR $\mathrm{Ca}^{2+}$ depletion and disease progression in HF (Kushnir and Marks 2010; Shan et al. 2010), and normalisation of this parameter has been seen to occur with LVAD support(Marx et al. 2000).

\subsubsection{Beta-adrenergic signalling}

Improvement of beta-AR ( $\beta$-AR) responsiveness and density occurs during LVAD therapy (Dipla et al. 1998; Klotz, S. et al. 2005a; Milting et al. 2006; Ogletree-Hughes et al. 2001), as well as mechanically unloaded failing rat hearts (Oriyanhan et al. 2007). LVAD induced $\beta$-AR "recovery" is independent of cessation of systemic $\beta$-AR agonist therapy (OgletreeHughes et al. 2001), of greater magnitude than that caused by pharmacotherapy alone (Klotz, S. et al. 2005a), and unrelated to duration of support (Ogletree-Hughes et al. 2001). Mechanisms promoting such recovery remain unclear and direct haemodynamic unloading and/or normalisation of cytokine and neurohumoral environment are likely to be important. Support for the the latter as the predominant governing factor is derived from results showing LVAD associated $\beta$-AR recovery to occur in both RV and LV, despite isolated LV haemodynamic unloading (Klotz, S. et al. 2005b). Alteration in the specific expression of genes involved in $\beta$-AR signalling such as phosphodiesterase 1A, 3B, calcineurin A and Rap guanine nucleotide exchange factor 4 RAPGEF4 (EPAC2) has been shown to coincide with functional myocardial recovery in patients undergoing device explantation (Hall et al. 2007). 


\subsubsection{Neurohumoral effects}

LVAD support is known to decrease plasma adrenaline, noradrenaline (NA), renin, aldosterone and vasopressin (Klotz et al. 2009) as well as Atrial and B-type natriuretic peptide plasma levels (Thompson et al. 2005), myocardial gene (Kuhn et al. 2004) and protein (Wohlschlaeger et al. 2008) expression. Occasional correlation between measured biomarkers and functional improvement raises the possibility of the potential use of such markers in guiding therapy and prediction of recovery (Thompson et al. 2005). However, LVAD effects on the RAAS have recently been shown to be complex, with actual increased myocardial Ang II and NA levels, occurring despite reductions in plasma renin and aldosterone levels (Klotz et al. 2009). Such changes are postulated to arise from an LVAD induced recovery of depleted angiotensinogen levels, leading to enhanced generation of myocardial Ang II with subsequent sympathetic stimulation causing elevated NA levels, and shown to correlate with increased fibrosis and ventricular stiffness (Klotz et al. 2009), structural changes that were prevented by ACE-I. The negative effects of NA and Ang II on ECM remodelling and apoptosis are well known (Bonnefont-Rousselot et al. 2002; Klotz, S. et al. 2007b), and such findings emphasise the importance of possible pharmacological manipulation of specific neuroendocrine pathways in combination with LVADs in promoting positive remodelling.

\subsection{Cell survival and regeneration}

\subsubsection{Apoptosis}

LVAD therapy appears to have beneficial effects on cell survival and apoptotic pathways although results are not uniform amongst studies. There are several distinct apoptotic pathways and their regulation is complex. Human HF is generally characterised by loss of cardiomyocytes (Narula et al. 2006) but rarely and inconsistently the presence of abundant apoptosis is demonstrated (Francis GS 1999).LVAD support causes normalisation and augmentation of anti-apoptotic proteins FasExo6Del (Bartling et al. 1999), BCL-XL levels (Milting et al. 1999), BCL-2 (Francis et al. 1999), decreased myocardial TNF- $\alpha$ levels (Razeghi et al. 2001; Torre-Amione et al. 1999), a cytokine believed to possess apoptotic regulatory properties, decreases in markers of DNA fragmentation (Bartling et al. 1999), cellular repair (PCNA) (Francis et al. 1999) and markers of cellular apoptosis(Baba et al. 2000).

\subsubsection{Cardiomyocyte regeneration}

LVAD-induced recovery of pro-apoptotic pathways activated in HF seemingly infers a potential for increased cell survival and augmentation of myocyte number, a mechanism that easily lends itself to promoting improved cardiac function and recovery. Previously held assumptions that cardiomyocytes are terminally differentiated, with severely limited, if any, potential to undergo mitotic division have now been challenged (Anversa and Kajstura 1998). Evidence showing that in response to injury cardiomyocyte division occurs (Beltrami et al. 2001; Engel et al. 2006), coupled to work demonstrating the existence of endogenous cardiac stem pools (Hosoda et al. 2010; Leri et al. 2005; Urbanek et al. 2005) naturally leads to the idea that together with the "anti-apoptotic" effects of LVAD therapy, the favourable biochemical and haemodynamic environment afforded by MU may also promote cardiac regeneration via increased cardiomyocyte division, or endogenous stem cell proliferation, thus reversing HF myocyte loss. 
Evidence in support of such an LVAD role is limited (Wohlschlaeger et al. 2010). Wohlschlaeger et al. recently showed a dramatic 2 fold reduction in mean cardiomyocyte DNA and a 2 fold increase in number of diploid cardiomyocytes, together with significant decrease in the number of polyploid cardiomyocytes, a characteristic of human cardiac hypertrophy (Adler and Sandritter 1980; Sandritter and Adler 1976; Wohlschlaeger et al. 2010). The authors propose that these findings can be explained by a single unifying theory, hypothesising LVAD support to a) ameliorate hypertrophic stimuli that promote the transition of "mitotically arrested" cardiomyocytes into the S phase of DNA replication (Busk et al. 2002) (reduction in polyploidy), as well as b) promote real cell division or progenitor cell proliferation (increase in diploidy and reduction of DNA content per cardiomyocyte). Such findings require further mechanistic study, but clearly demonstrate the plasticity and reversibility of the cardiomyocyte DNA phenotype in HF, and raise the attractive possibility of LVAD-induced cardiac regeneration.

\subsection{Myocardial metabolism and energetics}

Myocardial metabolism and energetics have been shown to be consistently altered in HF (Neubauer 2007), resulting in an energy deficient mechanically inefficient heart, characterised by diminished ATP and phosphocreatine levels (Ingwall and Weiss 2004; Starling et al. 1998). The exact mechanisms remain unclear, but altered carbohydrate metabolism and myocardial insulin resistance have been proposed as key determinants of deranged energetics in HF and a potential therapeutic target (Ashrafian et al. 2007). LVAD therapy has been associated with improved mitochondrial metabolic function (Lee et al. 1998), and normalisation of mitochondrial cardiolipin constitution in ICM (Heerdt et al. 2002).. In addition, normalisation of raised myocardial Arginine:glycine amidinotransferase (AGAT) mRNA levels, occurs in patients successfully undergoing LVAD explantation as part of the Harefield protocol (Hall et al. 2007), reinforcing the importance of altered metabolic pathways in HF pathogenesis and future therapy.

\subsection{IGF-1}

Insulin growth factor (IGF-1) has been shown to possess favourable cardiac effects in experimental models of HF, with both early and delayed short term IGF-1 administration causing cardiac hypertrophy and improvement in function (Duerr et al. 1995; Duerr et al. 1996). IGF-1 displays anti-apoptotic (Li et al. 1997) as well as regenerative properties in both skeletal (Musaro 2005; Pelosi et al. 2007) and cardiac muscle (Santini et al. 2007; Welch et al. 2002), with cardiac specific IGF-1 expression attenuating disease progression in a mouse model of DCM (Welch et al. 2002).

IGF-1 mRNA levels are elevated at time of explantation of LVAD in patients treated with the Harefield protocol, suggesting elevated IGF-1 levels maybe important for the recovery process (Barton et al. 2005). 2 clearly defined groups were identified: those in which IGF-1 mRNA was high at implantation in which it remained high, and those in which IGF-1 mRNA was low at implantation and increased significantly during recovery. It is highly likely that the increase in IGF-1 mRNA seen in this study is induced by the combination therapy used in the Harefield protocol, and not MU alone, as previous studies have shown no change in IGF-1 expression or IGF pathway activation during isolated LVAD support in patients bridged to transplantation (Hall et al. 2004; Razeghi et al. 2003).

Mechanisms governing the increase in IGF-1 and the subsequent role played in recovery are unclear. Findings of positive correlation between IGF-1 levels and MMPs 11, 14, TIMPs 1 
and 2 as well as stem cell recruitment factor SDF-1 expression, advocate modulation of the ECM and cellular regeneration to be important (Barton et al. 2005; Hall et al. 2004). Clenbuterol treatment of cultured cardiomyocytes has been shown to increase fibroblastderived IGF-1, causing myocyte hypertrophy via paracrine signalling (Bhavsar et al. 2010; Hall et al. 2004). This suggests that IGF-mediated prevention of myocardial atrophy may also be involved in promoting functional recovery.

\section{Clinical aspects of recovery}

\subsection{Pharmacological enhancement of myocardial recovery}

The evidence presented so far suggests that LVAD support can induce significant reverse remodelling in end stage HF, but on its own these changes rarely result in clinical recovery. However, combined pharmacological and LVAD therapy has been shown to achieve greatly improved rates of functional recovery (Birks et al. 2006; Birks et al. 2011) with the greatest rates of explantation being achieved using the Harefield protocol.

\subsection{Harefield protocol}

A clinical study at Harefield hospital in 2006 achieved an explantation rate of $73 \%$ using a novel pharmacological regimen involving the use of the drug clenbuterol, a $\beta_{2}$-AR agonist, in combination with aggressive high dose conventional medical therapy (lisinopril, carvedilol, spironolactone and losartan) (Birks et al. 2006) and pulsatile support. The purpose of this novel treatment strategy, was to enhance LVAD induced myocardial remodelling with high dose "conventional" pharmacotherapy (Phase 1), and prevent LVAD induced myocardial atrophy with high dose (up to $720 \mathrm{mcg}$ tds) clenbuterol (Phase 2). Despite the fact this study was a single centred, small, non-randomised study only involving a small number of patients $(n=15)$, all with non-ischaemic cardiomyopathy, the unprecedented high rates of recovery generated the notion that pharmacological $\beta_{2}$-AR stimulation may enhance myocardial recovery during LVAD therapy, and that future success in making BTR a widespread reality may rest, at least partially upon manipulation of this hitherto overlooked pathway. Support for this rationale has been further strengthened by recent results showing achievement of a $63.2 \%$ explantation rate, amongst a DCM cohort $(n=20)$, utilising the same protocol in combination with non-pulsatile mechanical support (Birks et al. 2011).

\subsection{Clenbuterol}

Clenbuterol is classified as being a selective $\beta_{2}$-AR agent (Baronti et al. 1978) with partial agonist activity, displaying a high affinity for both $\beta_{1}$-ARs and $\beta_{2}$-ARs in a variety of tissues (Cohen et al. 1982). $\beta_{2}$-AR stimulation by various agonists has been shown to cause skeletal muscle hypertrophy in several animal species (Kim et al. 1991). Subsequent results showing clenbuterol to possess a direct "physiological" cardiac hypertrophic effect (Hon et al. 2001) prompted its inclusion in Harefield protocol, primarily as an agent to prevent myocardial atrophy thought to occur with prolonged MU.

\subsection{Prevention of myocardial atrophy by clenbuterol}

Myocardial atrophy has been widely proposed as one of the mechanisms thwarting myocardial recovery during LVAD treatment of $\mathrm{HF}$, and a plausible explanation for low 
explantation rates. As part of the Harefield protocol, after stable regression of left ventricular end diastolic dimensions is confirmed echocardiographically over a 2 week period, phase 2 (duration at least $6 \mathrm{mths}$ ), consisting of carvedilol being switched to a specific $\beta_{1}$-AR bisoprolol, and the addition of high dose (titrated up to maximum dose of 720 mcg tds) clenbuterol, is commenced.

Lack of echocardiographic measures such as left ventricular posterior wall thickness or relative wall thickness (RWT: interventricular septum thickness + posterior wall thickness/LVEDd), a known predictor of cardiac stability after explantation (Dandel et al. 2008), coupled with the absence of a control group, make it difficult to assess whether "prevention of atrophy" actually occurred in this study. Recovery does not seem to correlate with myocyte size, suggesting that this is not the most important target promoting BTR (Terracciano et al. 2004). Evidence regarding an anti-atrophic action of clenbuterol is equivocal, with experimental studies both supporting (Soppa et al. 2008) as well as opposing (Tsuneyoshi et al. 2005) this effect. A separate small single centre clinical study showed clenbuterol therapy (maximum dose $720 \mathrm{mcg}$ od) during MU was effective in preventing cellular atrophy, despite no echocardiographic change in wall thickness (George et al. 2006).

\subsection{Other clenbuterol effects}

The exact mechanisms through which clenbuterol acts remains unclear, but extensive work undertaken over the last decade, has clearly established that beyond the purely hypertrophic or "anti-atrophic" effects, originally advocating clenbuterol's inclusion in the Harefield protocol, clenbuterol possesses a wide range of other positive actions. Clenbuterol administration for 1 week in normal rats has been shown to cause physiological hypertrophy, increased $\mathrm{Ca}^{2+}$ transient amplitude, increased SERCA 2a, PLB, NCX protein levels, and increased SR Ca ${ }^{2+}$ content (Soppa et al. 2005). Clenbuterol (1 week) has also been shown to enhance both whole heart and cellular function in chronically failing rodent myocardium, either alone or in combination with MU, with normalisation of myofilament sensitivity and APD duration and improved NCX activity (Soppa et al. 2008). Increased RyR2, SERCA2a protein expression and decreased apoptosis have been demonstrated in a similar model of HF after long term (9 weeks) clenbuterol therapy (Xydas et al. 2006). In addition, a clear cardioprotective inhibitory $G$ protein dependent anti-apoptotic effect of acute clenbuterol administration has been recently shown during ischaemia reperfusion (Zhang et al. 2010). Clenbuterol modulation of IGF-1 dependent regenerative and hypertrophic pathways, as well as ECM effects may also be responsible for promoting functional recovery (Barton et al. 2005; Bhavsar et al. 2010; Hall et al. 2004).

\subsection{Assessment of recovery \\ 3.6.1 Explantation criteria}

Echocardiographic, heamodynamic and exercise testing criteria form the foundation on which explantation decisions are made, but specific assessment methods and criteria vary between institutes. At the Berlin Heart Institute LVEF $>45 \%$, LVEDd $<55 \mathrm{~mm}$ in the presence of normal central pulmonary pressures, during reduced support (Dandel et al. 2008; Muller et al. 1997) mandates explantation, whereas Harefield hospital employs the criteria of LVEF $>45 \%$, LVEDd $<60 \mathrm{~mm}$, LVEDs $<50 \mathrm{~mm}$, pulmonary capillary wedge pressure $<12 \mathrm{~mm} \mathrm{Hg}$, cardiac index $>2.81 \mathrm{~min}^{-1}$ as well as exercise testing criteria, $\mathrm{VO}_{2}$ max of $>16 \mathrm{ml} \mathrm{kg-1} \mathrm{min}^{-1}$ during "off pump" testing (Birks et al. 2011). Dobutamine stress testing has also been successfully utilised at the Texas Heart Institute (Frazier and Myers 1999). 


\subsection{2 "Off pump" testing}

Off pump testing protocols have been developed relatively recently, and effectively involve cessation of pump flow (> 15 minutes) after systemic heparinisation, followed by assessment of heamodynamic and echocardiographic parameters at rest and after exercise. Turning off of pulsatile devices is acceptable, however turning off non-pulsatile devices leads to retrograde flow across the aortic valve, making functional assessment extremely difficult. This is avoided during testing by decreasing pump speed to $6000 \mathrm{RPM}$, resulting in zero forward or back flow, effectively ceasing haemodynamic support, or turning the pump "off". Such "off pump" testing has been shown to be safe and well tolerated in both types of device (Birks et al. 2011).

\subsubsection{Predictors of recovery}

Identification of factors favouring recovery has historically been extremely difficult. Molecular, histological and biochemical markers associated with functional improvement and with recovery have been identified (discussed earlier), but to date no recognised marker is featured in weaning criteria, which remains largely determined by echocardiographic and haemodynamic parameters. Short duration of HF has commonly but not always been shown to favour recovery (Birks et al. 2011), however, recovery of patients with long durations of HF has also been achieved. Echocardiographic parameters at time of LVAD implant are not predictive of recovery, although sustained improvement, as opposed to progressive deterioration in EF, fractional shortening and LV dimensions during LVAD therapy is associated with greater likelihood of explantation (Birks et al. 2011).

\subsubsection{Durability of myocardial recovery}

The potential therapeutic value of identifying predictors of relapse in preventing LVAD reimplantation has attracted huge interest. Dandel et al. identified support duration $>6$ months, LVEF $<45 \%$ and LVEDd $>55 \mathrm{~mm}$ at final pre explant echo, as well as a $>10 \%$ worsening of either of these parameters compared to best obtained value, to be highly predictive of early relapse (Dandel et al. 2008). These findings support the idea that prolonged MU beyond the "optimal point" results in redilatation and functional deterioration (Maybaum et al. 2007). In addition, $>10 \%$ decrease in relative wall thickness (RWT: interventricular septum thickness + posterior wall thickness/LVEDd), RWT of $<0.38$ and duration of $\mathrm{HF}>5$ years, also displayed positive predictive power for post LVAD cardiac instability. Post weaning deterioration in EF and LVEDd within the first 6 months increases risk of HF recurrence, highlighting the importance of early, regular functional surveillance of recovered patients.

\subsubsection{Factors opposing recovery}

It is proposed that as well as positive remodelling LVADs can induce negative remodelling. Negative remodelling of the ECM, and myocardial atrophy associated with prolonged MU are two potential barriers, thought to be opposing BTR, and pharmacological targeting of these components has yielded some clinical success. Regular and precise functional cardiac assessment during LVAD therapy is essential in promoting BTR. The increasing proportion of new generation devices being implanted as a means of DT in the US (Kirklin et al. 2011), in which functional recovery is neither expected, promoted, nor assessed may represent a significant new barrier to BTR. Consequently the fraction of LVADs being implanted in the 
US as a means of BTR is decreasing (Kirklin et al. 2011), and a lack of belief in, as well as desire to pursue BTR may mean potentially "recoverable" patients will not be optimised or even assessed for device explantation in the future.

\section{Conclusions}

Constantly improving technology, the advent of even smaller pumps allowing less traumatic implantation and explantation with fewer complications has already, and will continue to improve LVAD associated morbidity, mortality and quality of life (Rogers et al. 2010). Further use of this unique research vehicle to better understand the reversible mechanisms involved in HF pathogenesis, will identify new therapeutic targets amenable to manipulation. It is probable that if BTR is pursued in future years, recent success suggests it should be (Birks et al. 2006; Birks et al. 2011), combination therapy i.e. LVAD + pharmacotherapy (existing or novel), gene or stem cell therapy, and even a combination of these will yield enhanced rates of recovery. Desires to implant smaller devices in patients with less advanced disease, and implement novel partial unloading, or intermittent ventricular reloading strategies may further improve the BTR strategy and the results of such studies are eagerly awaited.

\section{References}

Adler, C. P. and Sandritter, W. 1980 Alterations of substances (DNA, myoglobin, myosin, protein) in experimentally induced cardiac hypertrophy and under the influence of drugs (isoproterenol, cytostatics, strophanthin) Basic Res. Cardiol. 75:(1) 126-138

Akgul, A., Skrabal, C. A., Thompson, L. O., Loebe, M., Lafuente, J. A., Noon, G. P., and Youker, K. A. 2004 Role of mast cells and their mediators in failing myocardium under mechanical ventricular support J. Heart Lung Transplant. 23:(6) 709-715

Altemose, G. T., Gritsus, V., Jeevanandam, V., Goldman, B., and Margulies, K. B. 1997 Altered myocardial phenotype after mechanical support in human beings with advanced cardiomyopathy J Heart Lung Transplant. 16:(7) 765-773

Anversa, P. and Kajstura, J. 13-7-1998 Ventricular myocytes are not terminally differentiated in the adult mammalian heart Circ.Res. 83:(1) 1-14

Arnold, J. M., Yusuf, S., Young, J., Mathew, J., Johnstone, D., Avezum, A., Lonn, E., Pogue, J., and Bosch, J. 11-3-2003 Prevention of Heart Failure in Patients in the Heart Outcomes Prevention Evaluation (HOPE) Study Circulation 107:(9) 1284-1290

Ashrafian, H., Frenneaux, M. P., and Opie, L. H. 24-7-2007 Metabolic mechanisms in heart failure Circulation 116:(4) 434-448

Avendano, G. F., Agarwal, R. K., Bashey, R. I., Lyons, M. M., Soni, B. J., Jyothirmayi, G. N., and Regan, T. J. 1999 Effects of glucose intolerance on myocardial function and collagen-linked glycation Diabetes 48:(7) 1443-1447

Baba, H. A., Grabellus, F., August, C., Plenz, G., Takeda, A., Tjan, T. D., Schmid, C., and Deng, M. C. 2000 Reversal of metallothionein expression is different throughout the human myocardium after prolonged left-ventricular mechanical support J.Heart Lung Transplant. 19:(7) 668-674

Badenhorst, D., Maseko, M., Tsotetsi, O. J., Naidoo, A., Brooksbank, R., Norton, G. R., and Woodiwiss, A. J. 2003 Cross-linking influences the impact of quantitative changes in myocardial collagen on cardiac stiffness and remodelling in hypertension in rats Cardiovasc.Res. 57:(3) 632-641 
Baronti, A., Griceo, A., and Vibelli, C. 31-5-1978 Study of a new oral beta-adrenergic drug, clenbuterol, in patients with chronic bronchitis Eur.J.Clin.Pharmacol. 13:(3) 171-177

Bartha, E., Kiss, G. N., Kalman, E., Kulcsar, G., Kalai, T., Hideg, K., Habon, T., Sumegi, B., Toth, K., and Halmosi, R. 2008 Effect of L-2286, a poly(ADP-ribose)polymerase inhibitor and enalapril on myocardial remodeling and heart failure J.Cardiovasc.Pharmacol. 52:(3) 253-261

Bartling, B., Milting, H., Schumann, H., Darmer, D., Arusoglu, L., Koerner, M. M., ElBanayosy, A., Koerfer, R., Holtz, J., and Zerkowski, H. R. 9-11-1999 Myocardial gene expression of regulators of myocyte apoptosis and myocyte calcium homeostasis during hemodynamic unloading by ventricular assist devices in patients with end-stage heart failure Circulation 100:(19 Suppl) II216-II223

Barton, P. J., Felkin, L. E., Birks, E. J., Cullen, M. E., Banner, N. R., Grindle, S., Hall, J. L., Miller, L. W., and Yacoub, M. H. 30-8-2005 Myocardial insulin-like growth factor-I gene expression during recovery from heart failure after combined left ventricular assist device and clenbuterol therapy Circulation 112:(9 Suppl) I46-I50

Beltrami, A. P., Urbanek, K., Kajstura, J., Yan, S. M., Finato, N., Bussani, R., Nadal-Ginard, B., Silvestri, F., Leri, A., Beltrami, C. A., and Anversa, P. 7-6-2001 Evidence that human cardiac myocytes divide after myocardial infarction N. Engl. J. Med. 344:(23) 1750-1757

Bers, D. M. 2006 Altered cardiac myocyte Ca regulation in heart failure Physiology. (Bethesda.) 21:() 380-387

Bhavsar, P. K., Brand, N. J., Felkin, L. E., Luther, P. K., Cullen, M. E., Yacoub, M. H., and Barton, P. J. 2010 Clenbuterol induces cardiac myocyte hypertrophy via paracrine signalling and fibroblast-derived IGF-1 J. Cardiovasc. Transl. Res. 3:(6) 688-695

Birks, E. J., George, R. S., Hedger, M., Bahrami, T., Wilton, P., Bowles, C. T., Webb, C., Bougard, R., Amrani, M., Yacoub, M. H., Dreyfus, G., and Khaghani, A. 1-2-2011 Reversal of severe heart failure with a continuous-flow left ventricular assist device and pharmacological therapy: a prospective study Circulation 123:(4) 381-390

Birks, E. J., Hall, J. L., Barton, P. J., Grindle, S., Latif, N., Hardy, J. P., Rider, J. E., Banner, N. R., Khaghani, A., Miller, L. W., and Yacoub, M. H. 30-8-2005 Gene profiling changes in cytoskeletal proteins during clinical recovery after left ventricular-assist device support Circulation 112:(9 Suppl) I57-I64

Birks, E. J., Latif, N., Owen, V., Bowles, C., Felkin, L. E., Mullen, A. J., Khaghani, A., Barton, P. J., Polak, J. M., Pepper, J. R., Banner, N. R., and Yacoub, M. H. 18-9-2001 Quantitative myocardial cytokine expression and activation of the apoptotic pathway in patients who require left ventricular assist devices Circulation 104:(12 Suppl 1) I233-I240

Birks, E. J., Tansley, P. D., Hardy, J., George, R. S., Bowles, C. T., Burke, M., Banner, N. R., Khaghani, A., and Yacoub, M. H. 2-11-2006 Left ventricular assist device and drug therapy for the reversal of heart failure N. Engl. J Med. 355:(18) 1873-1884

Bonnefont-Rousselot, D., Mahmoudi, A., Mougenot, N., Varoquaux, O., Le, Nahour G., Fouret, P., and Lechat, P. 2002 Catecholamine effects on cardiac remodelling, oxidative stress and fibrosis in experimental heart failure Redox. Rep. 7:(3) 145-151

Bouchard, R. A., Clark, R. B., and Giles, W. R. 1995 Effects of action potential duration on excitation-contraction coupling in rat ventricular myocytes. Action potential voltage-clamp measurements Circ. Res. 76:(5) 790-801 
Bruckner, B. A., Stetson, S. J., Farmer, J. A., Radovancevic, B., Frazier, O. H., Noon, G. P., Entman, M. L., Torre-Amione, G., and Youker, K. A. 2000 The implications for cardiac recovery of left ventricular assist device support on myocardial collagen content Am J Surg. 180:(6) 498-501

Bruckner, B. A., Stetson, S. J., Perez-Verdia, A., Youker, K. A., Radovancevic, B., Connelly, J. H., Koerner, M. M., Entman, M. E., Frazier, O. H., Noon, G. P., and Torre-Amione, G. 2001 Regression of fibrosis and hypertrophy in failing myocardium following mechanical circulatory support J Heart Lung Transplant. 20:(4) 457-464

Bruggink, A. H., van Oosterhout, M. F., De, Jonge N., Ivangh, B., van, Kuik J., Voorbij, R. H., Cleutjens, J. P., Gmelig-Meyling, F. H., and De Weger, R. A. 2006 Reverse remodeling of the myocardial extracellular matrix after prolonged left ventricular assist device support follows a biphasic pattern J Heart Lung Transplant. 25:(9) 1091-1098

Busk, P. K., Bartkova, J., Strom, C. C., Wulf-Andersen, L., Hinrichsen, R., Christoffersen, T. E., Latella, L., Bartek, J., Haunso, S., and Sheikh, S. P. 2002 Involvement of cyclin D activity in left ventricle hypertrophy in vivo and in vitro Cardiovasc. Res. 56:(1) 6475

Chaudhary, K. W., Rossman, E. I., Piacentino, V., III, Kenessey, A., Weber, C., Gaughan, J. P., Ojamaa, K., Klein, I., Bers, D. M., Houser, S. R., and Margulies, K. B. 18-8-2004 Altered myocardial Ca2+ cycling after left ventricular assist device support in the failing human heart J Am Coll.Cardiol. 44:(4) 837-845

Cohen, M. L., Wiley, K. S., and Bemis, K. G. 1982 Analysis of the beta 1 and beta 2 adrenoceptor interactions of the partial agonist, clenbuterol (NAB365), in the rat jugular vein and atria Naunyn Schmiedebergs Arch.Pharmacol. 320:(2) 145-151

Cohn, J. N. 15-8-1996 The management of chronic heart failure N.Engl.J.Med. 335:(7) 490-498

Dandel, M., Weng, Y., Siniawski, H., Potapov, E., Drews, T., Lehmkuhl, H. B., Knosalla, C., and Hetzer, R. 30-9-2008 Prediction of cardiac stability after weaning from left ventricular assist devices in patients with idiopathic dilated cardiomyopathy 17 Circulation 118:(14 Suppl) S94-105

Dandel, M., Weng, Y., Siniawski, H., Potapov, E., Lehmkuhl, H. B., and Hetzer, R. 30-8-2005 Long-term results in patients with idiopathic dilated cardiomyopathy after weaning from left ventricular assist devices Circulation 112:(9 Suppl) I37-I45

De, Jonge N., van Wichen, D. F., Schipper, M. E., Lahpor, J. R., Gmelig-Meyling, F. H., Robles de Medina, E. O., and De Weger, R. A. 20-3-2002 Left ventricular assist device in end-stage heart failure: persistence of structural myocyte damage after unloading. An immunohistochemical analysis of the contractile myofilaments J.Am.Coll.Cardiol. 39:(6) 963-969

Delgado, R., III, Radovancevic, B., Massin, E. K., Frazier, O. H., and Benedict, C. 1998 Neurohormonal changes after implantation of a left ventricular assist system ASAIO J. 44:(4) 299-302

Dipla, K., Mattiello, J. A., Jeevanandam, V., Houser, S. R., and Margulies, K. B. 16-6-1998 Myocyte recovery after mechanical circulatory support in humans with end-stage heart failure Circulation 97:(23) 2316-2322

Duerr, R. L., Huang, S., Miraliakbar, H. R., Clark, R., Chien, K. R., and Ross, J., Jr. 1995 Insulin-like growth factor-1 enhances ventricular hypertrophy and function during the onset of experimental cardiac failure J.Clin.Invest 95:(2) 619-627 
Duerr, R. L., McKirnan, M. D., Gim, R. D., Clark, R. G., Chien, K. R., and Ross, J., Jr. 15-61996 Cardiovascular effects of insulin-like growth factor-1 and growth hormone in chronic left ventricular failure in the rat Circulation 93:(12) 2188-2196

Engel, F. B., Hsieh, P. C., Lee, R. T., and Keating, M. T. 17-10-2006 FGF1/p38 MAP kinase inhibitor therapy induces cardiomyocyte mitosis, reduces scarring, and rescues function after myocardial infarction Proc.Natl.Acad.Sci.U.S.A 103:(42) 15546-15551

Farrar, D. J., Holman, W. R., McBride, L. R., Kormos, R. L., Icenogle, T. B., Hendry, P. J., Moore, C. H., Loisance, D. Y., El-Banayosy, A., and Frazier, H. 2002 Long-term follow-up of Thoratec ventricular assist device bridge-to-recovery patients successfully removed from support after recovery of ventricular function J.Heart Lung Transplant. 21:(5) 516-521

Felkin, L. E., Lara-Pezzi, E., George, R., Yacoub, M. H., Birks, E. J., and Barton, P. J. 2009 Expression of extracellular matrix genes during myocardial recovery from heart failure after left ventricular assist device support J.Heart Lung Transplant. 28:(2) 117-122

Francis, G. S., Anwar, F., Bank, A. J., Kubo, S. H., and Jessurun, J. 1999 Apoptosis, Bcl-2, and proliferating cell nuclear antigen in the failing human heart: observations made after implantation of left ventricular assist device J.Card Fail. 5:(4) 308-315

Frazier, O. H. 1994 First use of an untethered, vented electric left ventricular assist device for long-term support Circulation 89:(6) 2908-2914

Frazier, O. H., Benedict, C. R., Radovancevic, B., Bick, R. J., Capek, P., Springer, W. E., Macris, M. P., Delgado, R., and Buja, L. M. 1996 Improved left ventricular function after chronic left ventricular unloading 1 Ann.Thorac.Surg. 62:(3) 675-681

Frazier, O. H. and Myers, T. J. 1999 Left ventricular assist system as a bridge to myocardial recovery Ann.Thorac.Surg. 68:(2) 734-741

Gaughan, J. P., Furukawa, S., Jeevanandam, V., Hefner, C. A., Kubo, H., Margulies, K. B., McGowan, B. S., Mattiello, J. A., Dipla, K., Piacentino, V., III, Li, S., and Houser, S. R. 1999 Sodium/calcium exchange contributes to contraction and relaxation in failed human ventricular myocytes Am.J.Physiol 277:(2 Pt 2) H714-H724

George, I., Xydas, S., Mancini, D. M., LaManca, J., DiTullio, M., Marboe, C. C., Shane, E., Schulman, A. R., Colley, P. M., Petrilli, C. M., Naka, Y., Oz, M. C., and Maybaum, S. 2006 Effect of clenbuterol on cardiac and skeletal muscle function during left ventricular assist device support 8 J.Heart Lung Transplant. 25:(9) 1084-1090

Gwathmey, J. K., Copelas, L., MacKinnon, R., Schoen, F. J., Feldman, M. D., Grossman, W., and Morgan, J. P. 1987 Abnormal intracellular calcium handling in myocardium from patients with end-stage heart failure Circ.Res. 61:(1) 70-76

Hall, J. L., Birks, E. J., Grindle, S., Cullen, M. E., Barton, P. J., Rider, J. E., Lee, S., Harwalker, S., Mariash, A., Adhikari, N., Charles, N. J., Felkin, L. E., Polster, S., George, R. S., Miller, L. W., and Yacoub, M. H. 2007 Molecular signature of recovery following combination left ventricular assist device (LVAD) support and pharmacologic therapy Eur.Heart J. 28:(5) 613-627

Hall, J. L., Grindle, S., Han, X., Fermin, D., Park, S., Chen, Y., Bache, R. J., Mariash, A., Guan, Z., Ormaza, S., Thompson, J., Graziano, J., de Sam Lazaro, S. E., Pan, S., Simari, R. D., and Miller, L. W. 19-5-2004 Genomic profiling of the human heart before and after mechanical support with a ventricular assist device reveals alterations in vascular signaling networks Physiol Genomics 17:(3) 283-291 
Harding, J. D., Piacentino, V., III, Gaughan, J. P., Houser, S. R., and Margulies, K. B. 11-92001 Electrophysiological alterations after mechanical circulatory support in patients with advanced cardiac failure Circulation 104:(11) 1241-1247

Hasenfuss, G., Schillinger, W., Lehnart, S. E., Preuss, M., Pieske, B., Maier, L. S., Prestle, J., Minami, K., and Just, H. 9-2-1999 Relationship between Na+-Ca2+-exchanger protein levels and diastolic function of failing human myocardium Circulation 99:(5) 641-648

Heerdt, P. M., Holmes, J. W., Cai, B., Barbone, A., Madigan, J. D., Reiken, S., Lee, D. L., Oz, M. C., Marks, A. R., and Burkhoff, D. 28-11-2000a Chronic unloading by left ventricular assist device reverses contractile dysfunction and alters gene expression in end-stage heart failure Circulation 102:(22) 2713-2719

Heerdt, P. M., Holmes, J. W., Cai, B., Barbone, A., Madigan, J. D., Reiken, S., Lee, D. L., Oz, M. C., Marks, A. R., and Burkhoff, D. 28-11-2000b Chronic unloading by left ventricular assist device reverses contractile dysfunction and alters gene expression in end-stage heart failure Circulation 102:(22) 2713-2719

Heerdt, P. M., Schlame, M., Jehle, R., Barbone, A., Burkhoff, D., and Blanck, T. J. 2002 Disease-specific remodeling of cardiac mitochondria after a left ventricular assist device Ann.Thorac.Surg. 73:(4) 1216-1221

Hetzer, R., Muller, J. H., Weng, Y. G., Loebe, M., and Wallukat, G. 2000 Midterm follow-up of patients who underwent removal of a left ventricular assist device after cardiac recovery from end-stage dilated cardiomyopathy J Thorac.Cardiovasc.Surg. 120:(5) 843-853

Hon, J. K., Steendijk, P., Petrou, M., Wong, K., and Yacoub, M. H. 2001 Influence of clenbuterol treatment during six weeks of chronic right ventricular pressure overload as studied with pressure-volume analysis 21 J.Thorac.Cardiovasc.Surg. 122:(4) 767-774

Hosoda, T., Kajstura, J., Leri, A., and Anversa, P. 2010 Mechanisms of myocardial regeneration Circ.J. 74:(1) 13-17

Hubler, S., Potapov, E. V., Loebe, M., Nasseri, B. A., Gosmann, D., Hoffmann, K., Sodian, R., Hausmann, H., and Hetzer, R. 2003 Development of a database of patients supported by ventricular assist devices ASAIO J. 49:(3) 340-344

Hunt, S. A., Abraham, W. T., Chin, M. H., Feldman, A. M., Francis, G. S., Ganiats, T. G., Jessup, M., Konstam, M. A., Mancini, D. M., Michl, K., Oates, J. A., Rahko, P. S., Silver, M. A., Stevenson, L. W., and Yancy, C. W. 14-4-2009a 2009 Focused update incorporated into the ACC/AHA 2005 Guidelines for the Diagnosis and Management of Heart Failure in Adults A Report of the American College of Cardiology Foundation/American Heart Association Task Force on Practice Guidelines Developed in Collaboration With the International Society for Heart and Lung Transplantation J.Am.Coll.Cardiol. 53:(15) e1-e90

Hunt, S. A., Abraham, W. T., Chin, M. H., Feldman, A. M., Francis, G. S., Ganiats, T. G., Jessup, M., Konstam, M. A., Mancini, D. M., Michl, K., Oates, J. A., Rahko, P. S., Silver, M. A., Stevenson, L. W., and Yancy, C. W. 14-4-2009b 2009 focused update incorporated into the ACC/AHA 2005 Guidelines for the Diagnosis and Management of Heart Failure in Adults: a report of the American College of Cardiology Foundation/American Heart Association Task Force on Practice Guidelines: developed in collaboration with the International Society for Heart and Lung Transplantation Circulation 119:(14) e391-e479 
Ibrahim, M. A., Ashour, O. M., Ibrahim, Y. F., El-Bitar, H. I., Gomaa, W., and bdel-Rahim, S. R. 2009 Angiotensin-converting enzyme inhibition and angiotensin AT(1)-receptor antagonism equally improve doxorubicin-induced cardiotoxicity and nephrotoxicity Pharmacol.Res. 60:(5) 373-381

Ingwall, J. S. and Weiss, R. G. 23-7-2004 Is the failing heart energy starved? On using chemical energy to support cardiac function Circ.Res. 95:(2) 135-145

Jessup, M. and Brozena, S. 15-5-2003 Heart failure N.Engl.J.Med. 348:(20) 2007-2018

Kim, Y. S., Sainz, R. D., Molenaar, P., and Summers, R. J. 9-10-1991 Characterization of beta 1 - and beta 2-adrenoceptors in rat skeletal muscles 1 Biochem.Pharmacol. 42:(9) 1783-1789

Kirklin, J. K., Naftel, D. C., Kormos, R. L., Stevenson, L. W., Pagani, F. D., Miller, M. A., Ulisney, K. L., Baldwin, J. T., and Young, J. B. 2011 Third INTERMACS Annual Report: the evolution of destination therapy in the United States J.Heart Lung Transplant. 30:(2) 115-123

Klotz, S., Barbone, A., Reiken, S., Holmes, J. W., Naka, Y., Oz, M. C., Marks, A. R., and Burkhoff, D. 1-3-2005a Left ventricular assist device support normalizes left and right ventricular beta-adrenergic pathway properties J.Am.Coll.Cardiol. 45:(5) 668676

Klotz, S., Burkhoff, D., Garrelds, I. M., Boomsma, F., and Danser, A. H. 2009 The impact of left ventricular assist device-induced left ventricular unloading on the myocardial renin-angiotensin-aldosterone system: therapeutic consequences? Eur.Heart J. 30:(7) 805-812

Klotz, S., Danser, A. H., Foronjy, R. F., Oz, M. C., Wang, J., Mancini, D., D'Armiento, J., and Burkhoff, D. 20-3-2007a The impact of angiotensin-converting enzyme inhibitor therapy on the extracellular collagen matrix during left ventricular assist device support in patients with end-stage heart failure J Am Coll.Cardiol. 49:(11) 1166-1174

Klotz, S., Danser, A. H., Foronjy, R. F., Oz, M. C., Wang, J., Mancini, D., D'Armiento, J., and Burkhoff, D. 20-3-2007b The impact of angiotensin-converting enzyme inhibitor therapy on the extracellular collagen matrix during left ventricular assist device support in patients with end-stage heart failure J Am Coll.Cardiol. 49:(11) 1166-1174

Klotz, S., Foronjy, R. F., Dickstein, M. L., Gu, A., Garrelds, I. M., Danser, A. H., Oz, M. C., D'Armiento, J., and Burkhoff, D. 19-7-2005b Mechanical unloading during left ventricular assist device support increases left ventricular collagen cross-linking and myocardial stiffness Circulation 112:(3) 364-374

Klotz, S., Jan Danser, A. H., and Burkhoff, D. 2008 Impact of left ventricular assist device (LVAD) support on the cardiac reverse remodeling process Prog.Biophys.Mol.Biol. 97:(2-3) 479-496

Komuro, I., Wenninger, K. E., Philipson, K. D., and Izumo, S. 15-5-1992 Molecular cloning and characterization of the human cardiac $\mathrm{Na}+\mathrm{Ca} 2+$ exchanger cDNA Proc.Natl.Acad.Sci.U.S.A 89:(10) 4769-4773

Koss, K. L., Grupp, I. L., and Kranias, E. G. 1997 The relative phospholamban and SERCA2 ratio: a critical determinant of myocardial contractility Basic Res.Cardiol. 92 Suppl 1:() 17-24

Kuhn, M., Voss, M., Mitko, D., Stypmann, J., Schmid, C., Kawaguchi, N., Grabellus, F., and Baba, H. A. 1-11-2004 Left ventricular assist device support reverses altered cardiac expression and function of natriuretic peptides and receptors in end-stage heart failure Cardiovasc.Res. 64:(2) 308-314 
Kushnir, A. and Marks, A. R. 2010 The ryanodine receptor in cardiac physiology and disease Adv.Pharmacol. 59:() 1-30

Latif, N., Yacoub, M. H., George, R., Barton, P. J., and Birks, E. J. 2007 Changes in sarcomeric and non-sarcomeric cytoskeletal proteins and focal adhesion molecules during clinical myocardial recovery after left ventricular assist device support J.Heart Lung Transplant. 26:(3) 230-235

Lee, S. H., Doliba, N., Osbakken, M., Oz, M., and Mancini, D. 1998 Improvement of myocardial mitochondrial function after hemodynamic support with left ventricular assist devices in patients with heart failure J.Thorac.Cardiovasc.Surg. 116:(2) 344-349

Leri, A., Kajstura, J., and Anversa, P. 2005 Cardiac stem cells and mechanisms of myocardial regeneration Physiol Rev. 85:(4) 1373-1416

Levin, H. R., Oz, M. C., Chen, J. M., Packer, M., Rose, E. A., and Burkhoff, D. 1-6-1995 Reversal of chronic ventricular dilation in patients with end-stage cardiomyopathy by prolonged mechanical unloading Circulation 91:(11) 2717-2720

Li, Q., Li, B., Wang, X., Leri, A., Jana, K. P., Liu, Y., Kajstura, J., Baserga, R., and Anversa, P. 15-10-1997 Overexpression of insulin-like growth factor-1 in mice protects from myocyte death after infarction, attenuating ventricular dilation, wall stress, and cardiac hypertrophy J.Clin.Invest 100:(8) 1991-1999

Li, Y. Y., Feng, Y., McTiernan, C. F., Pei, W., Moravec, C. S., Wang, P., Rosenblum, W., Kormos, R. L., and Feldman, A. M. 4-9-2001 Downregulation of matrix metalloproteinases and reduction in collagen damage in the failing human heart after support with left ventricular assist devices Circulation 104:(10) 1147-1152

Madigan, J. D., Barbone, A., Choudhri, A. F., Morales, D. L., Cai, B., Oz, M. C., and Burkhoff, D. 2001 Time course of reverse remodeling of the left ventricle during support with a left ventricular assist device J.Thorac.Cardiovasc.Surg. 121:(5) 902-908

Mancini, D. and Lietz, K. 13-7-2010 Selection of cardiac transplantation candidates in 2010 Circulation 122:(2) 173-183

Mann, D. L. and Spinale, F. G. 27-10-1998 Activation of matrix metalloproteinases in the failing human heart: breaking the tie that binds Circulation 98:(17) 1699-1702

Marijianowski, M. M., Teeling, P., Mann, J., and Becker, A. E. 1995 Dilated cardiomyopathy is associated with an increase in the type I/type III collagen ratio: a quantitative assessment J.Am.Coll.Cardiol. 25:(6) 1263-1272

Marx, S. O., Reiken, S., Hisamatsu, Y., Jayaraman, T., Burkhoff, D., Rosemblit, N., and Marks, A. R. 12-5-2000 PKA phosphorylation dissociates FKBP12.6 from the calcium release channel (ryanodine receptor): defective regulation in failing hearts Cell 101:(4) 365-376

Matsumiya, G., Monta, O., Fukushima, N., Sawa, Y., Funatsu, T., Toda, K., and Matsuda, H. 2005 Who would be a candidate for bridge to recovery during prolonged mechanical left ventricular support in idiopathic dilated cardiomyopathy? J.Thorac.Cardiovasc.Surg. 130:(3) 699-704

Maybaum, S., Kamalakannan, G., and Murthy, S. 2008 Cardiac recovery during mechanical assist device support Semin.Thorac.Cardiovasc.Surg. 20:(3) 234-246

Maybaum, S., Mancini, D., Xydas, S., Starling, R. C., Aaronson, K., Pagani, F. D., Miller, L. W., Margulies, K., McRee, S., Frazier, O. H., and Torre-Amione, G. 15-5-2007 Cardiac improvement during mechanical circulatory support: a prospective multicenter study of the LVAD Working Group Circulation 115:(19) 2497-2505 
Mayosi, B. M. 2007 Contemporary trends in the epidemiology and management of cardiomyopathy and pericarditis in sub-Saharan Africa Heart 93:(10) 1176-1183

McCarthy, P. M., Savage, R. M., Fraser, C. D., Vargo, R., James, K. B., Goormastic, M., and Hobbs, R. E. 1995 Hemodynamic and physiologic changes during support with an implantable left ventricular assist device J Thorac.Cardiovasc.Surg. 109:(3) 409-417

Mehta, S. M., Aufiero, T. X., Pae, W. E., Jr., Miller, C. A., and Pierce, W. S. 1996 Results of mechanical ventricular assistance for the treatment of post cardiotomy cardiogenic shock ASAIO J. 42:(3) 211-218

Meng, G., Wu, F., Yang, L., Zhu, H., Gu, J., He, M., and Xu, J. 2009 Synergistic attenuation of myocardial fibrosis in spontaneously hypertensive rats by joint treatment with benazepril and candesartan J.Cardiovasc.Pharmacol. 54:(1) 16-24

Milting, H., Bartling, B., Schumann, H., El-Banayosy, A., Wlost, S., Ruter, F., Darmer, D., Holtz, J., Korfer, R., and Zerkowski, H. R. 1999 Altered levels of mRNA of apoptosis-mediating genes after mid-term mechanical ventricular support in dilative cardiomyopathy--first results of the Halle Assist Induced Recovery Study (HAIR) Thorac.Cardiovasc.Surg. 47:(1) 48-50

Milting, H., Scholz, C., Arusoglu, L., Freitag, M., Cebulla, R., Jaquet, K., Korfer, R., Lewinski, V., Kassner, A., Brodde, O. E., Kogler, H., El, Banayosy A., and Pieske, B. 2006 Selective upregulation of beta1-adrenergic receptors and dephosphorylation of troponin I in end-stage heart failure patients supported by ventricular assist devices J.Mol.Cell Cardiol. 41:(3) 441-450

Mohapatra, B., Vick, G. W., III, Fraser, C. D., Jr., Clunie, S. K., Towbin, J. A., Sinagra, G., and Vatta, M. 2010 Short-term mechanical unloading and reverse remodeling of failing hearts in children J.Heart Lung Transplant. 29:(1) 98-104

Mukherjee, D. and Sen, S. 1991 Alteration of collagen phenotypes in ischemic cardiomyopathy J.Clin.Invest 88:(4) 1141-1146

Muller, J., Wallukat, G., Weng, Y. G., Dandel, M., Spiegelsberger, S., Semrau, S., Brandes, K., Theodoridis, V., Loebe, M., Meyer, R., and Hetzer, R. 15-7-1997 Weaning from mechanical cardiac support in patients with idiopathic dilated cardiomyopathy Circulation 96:(2) 542-549

Musaro, A. 2005 Growth factor enhancement of muscle regeneration: a central role of IGF-1 Arch.Ital.Biol. 143:(3-4) 243-248

Narula, J., Haider, N., Arbustini, E., and Chandrashekhar, Y. 2006 Mechanisms of disease: apoptosis in heart failure--seeing hope in death Nat.Clin.Pract.Cardiovasc.Med. 3:(12) 681-688

Neubauer, S. 15-3-2007 The failing heart--an engine out of fuel N.Engl.J.Med. 356:(11) 11401151

Ogletree, M. L., Sweet, W. E., Talerico, C., Klecka, M. E., Young, J. B., Smedira, N. G., Starling, R. C., and Moravec, C. S. 2010 Duration of left ventricular assist device support: Effects on abnormal calcium cycling and functional recovery in the failing human heart J.Heart Lung Transplant. 29:(5) 554-561

Ogletree-Hughes, M. L., Stull, L. B., Sweet, W. E., Smedira, N. G., McCarthy, P. M., and Moravec, C. S. 21-8-2001 Mechanical unloading restores beta-adrenergic responsiveness and reverses receptor downregulation in the failing human heart Circulation 104:(8) 881-886 
Oriyanhan, W., Tsuneyoshi, H., Nishina, T., Matsuoka, S., Ikeda, T., and Komeda, M. 2007 Determination of optimal duration of mechanical unloading for failing hearts to achieve bridge to recovery in a rat heterotopic heart transplantation model J Heart Lung Transplant. 26:(1) 16-23

Pelosi, L., Giacinti, C., Nardis, C., Borsellino, G., Rizzuto, E., Nicoletti, C., Wannenes, F., Battistini, L., Rosenthal, N., Molinaro, M., and Musaro, A. 2007 Local expression of IGF-1 accelerates muscle regeneration by rapidly modulating inflammatory cytokines and chemokines FASEB J. 21:(7) 1393-1402

Pieske, B., Sutterlin, M., Schmidt-Schweda, S., Minami, K., Meyer, M., Olschewski, M., Holubarsch, C., Just, H., and Hasenfuss, G. 1-8-1996 Diminished post-rest potentiation of contractile force in human dilated cardiomyopathy. Functional evidence for alterations in intracellular Ca2+ handling J.Clin.Invest 98:(3) 764-776

Porter, K. E. and Turner, N. A. 2009 Cardiac fibroblasts: at the heart of myocardial remodeling Pharmacol.Ther. 123:(2) 255-278

Razeghi, P., Bruckner, B. A., Sharma, S., Youker, K. A., Frazier, O. H., and Taegtmeyer, H. 2003 Mechanical unloading of the failing human heart fails to activate the protein kinase B/Akt/glycogen synthase kinase-3beta survival pathway Cardiology 100:(1) $17-22$

Razeghi, P., Mukhopadhyay, M., Myers, T. J., Williams, J. N., Moravec, C. S., Frazier, O. H., and Taegtmeyer, H. 2001 Myocardial tumor necrosis factor-alpha expression does not correlate with clinical indices of heart failure in patients on left ventricular assist device support Ann.Thorac.Surg. 72:(6) 2044-2050

Rogers, J. G., Aaronson, K. D., Boyle, A. J., Russell, S. D., Milano, C. A., Pagani, F. D., Edwards, B. S., Park, S., John, R., Conte, J. V., Farrar, D. J., and Slaughter, M. S. 27-42010 Continuous flow left ventricular assist device improves functional capacity and quality of life of advanced heart failure patients J.Am.Coll.Cardiol. 55:(17) 1826-1834

Saito, S., Matsumiya, G., Sakaguchi, T., Miyagawa, S., Yamauchi, T., Kuratani, T., and Sawa, Y. 2010 Cardiac fibrosis and cellular hypertrophy decrease the degree of reverse remodeling and improvement in cardiac function during left ventricular assist J.Heart Lung Transplant. 29:(6) 672-679

Sandritter, W. and Adler, C. P. 26-5-1976 Polyploidization of heart muscle nuclei as a prerequisite for heart growth and numerical hyperplasia in heart hypertrophy Recent Adv.Stud.Cardiac.Struct.Metab 12:() 115-127

Santini, M. P., Tsao, L., Monassier, L., Theodoropoulos, C., Carter, J., Lara-Pezzi, E., Slonimsky, E., Salimova, E., Delafontaine, P., Song, Y. H., Bergmann, M., Freund, C., Suzuki, K., and Rosenthal, N. 22-6-2007 Enhancing repair of the mammalian heart Circ.Res. 100:(12) 1732-1740

Shahar, E., Lee, S., Kim, J., Duval, S., Barber, C., and Luepker, R. V. 2004 Hospitalized heart failure: rates and long-term mortality J.Card Fail. 10:(5) 374-379

Shan, J., Betzenhauser, M. J., Kushnir, A., Reiken, S., Meli, A. C., Wronska, A., Dura, M., Chen, B. X., and Marks, A. R. 1-12-2010 Role of chronic ryanodine receptor phosphorylation in heart failure and beta-adrenergic receptor blockade in mice J.Clin.Invest 120:(12) 4375-4387

Simon, M. A., Kormos, R. L., Murali, S., Nair, P., Heffernan, M., Gorcsan, J., Winowich, S., and McNamara, D. M. 30-8-2005 Myocardial recovery using ventricular assist 
devices: prevalence, clinical characteristics, and outcomes Circulation 112:(9 Suppl) I32-I36

Soppa, G. K., Lee, J., Stagg, M. A., Felkin, L. E., Barton, P. J., Siedlecka, U., Youssef, S., Yacoub, M. H., and Terracciano, C. M. 1-3-2008 Role and possible mechanisms of clenbuterol in enhancing reverse remodelling during mechanical unloading in murine heart failure Cardiovasc.Res 77:(4) 695-706

Soppa, G. K., Smolenski, R. T., Latif, N., Yuen, A. H., Malik, A., Karbowska, J., Kochan, Z., Terracciano, C. M., and Yacoub, M. H. 2005 Effects of chronic administration of clenbuterol on function and metabolism of adult rat cardiac muscle Am J Physiol Heart Circ Physiol 288:(3) H1468-H1476

Spinale, F. G., Coker, M. L., Heung, L. J., Bond, B. R., Gunasinghe, H. R., Etoh, T., Goldberg, A. T., Zellner, J. L., and Crumbley, A. J. 17-10-2000 A matrix metalloproteinase induction/activation system exists in the human left ventricular myocardium and is upregulated in heart failure Circulation 102:(16) 1944-1949

Starling, R. C., Hammer, D. F., and Altschuld, R. A. 1998 Human myocardial ATP content and in vivo contractile function Mol.Cell Biochem. 180:(1-2) 171-177

Sylvin, E. A., Stern, D. R., and Goldstein, D. J. 2010 Mechanical support for postcardiotomy cardiogenic shock: has progress been made? J.Card Surg. 25:(4) 442-454

Takaseya, T., Ishimatsu, M., Tayama, E., Nishi, A., Akasu, T., and Aoyagi, S. 7-12-2004 Mechanical unloading improves intracellular $\mathrm{Ca} 2+$ regulation in rats with doxorubicin-induced cardiomyopathy J Am Coll.Cardiol. 44:(11) 2239-2246

Terracciano, C. M., Hardy, J., Birks, E. J., Khaghani, A., Banner, N. R., and Yacoub, M. H. 185-2004 Clinical recovery from end-stage heart failure using left-ventricular assist device and pharmacological therapy correlates with increased sarcoplasmic reticulum calcium content but not with regression of cellular hypertrophy Circulation 109:(19) 2263-2265

Terracciano, C. M., Koban, M. U., Soppa, G. K., Siedlecka, U., Lee, J., Stagg, M. A., and Yacoub, M. H. 2007 The role of the cardiac Na+/Ca2+ exchanger in reverse remodeling: relevance for LVAD-recovery Ann.N.Y.Acad.Sci. 1099:() 349-360

Terracciano, C. M., Miller, L. W., and Yacoub, M. H. 2010 Contemporary use of ventricular assist devices Annu.Rev.Med. 61:() 255-270

Thohan, V., Stetson, S. J., Nagueh, S. F., Rivas-Gotz, C., Koerner, M. M., Lafuente, J. A., Loebe, M., Noon, G. P., and Torre-Amione, G. 2005 Cellular and hemodynamics responses of failing myocardium to continuous flow mechanical circulatory support using the DeBakey-Noon left ventricular assist device: a comparative analysis with pulsatile-type devices J.Heart Lung Transplant. 24:(5) 566-575

Thompson, L. O., Skrabal, C. A., Loebe, M., Lafuente, J. A., Roberts, R. R., Akgul, A., Jones, V., Bruckner, B. A., Thohan, V., Noon, G. P., and Youker, K. A. 2005 Plasma neurohormone levels correlate with left ventricular functional and morphological improvement in LVAD patients J.Surg.Res. 123:(1) 25-32

Torre-Amione, G., Stetson, S. J., Youker, K. A., Durand, J. B., Radovancevic, B., Delgado, R. M., Frazier, O. H., Entman, M. L., and Noon, G. P. 14-9-1999 Decreased expression of tumor necrosis factor-alpha in failing human myocardium after mechanical circulatory support : A potential mechanism for cardiac recovery Circulation 100:(11) 1189-1193 
Trulock, E. P., Christie, J. D., Edwards, L. B., Boucek, M. M., Aurora, P., Taylor, D. O., Dobbels, F., Rahmel, A. O., Keck, B. M., and Hertz, M. I. 2007 Registry of the International Society for Heart and Lung Transplantation: twenty-fourth official adult lung and heart-lung transplantation report-2007 J.Heart Lung Transplant. 26:(8) 782-795

Tsuneyoshi, H., Oriyanhan, W., Kanemitsu, H., Shiina, R., Nishina, T., Matsuoka, S., Ikeda, T., and Komeda, M. 30-8-2005 Does the beta2-agonist clenbuterol help to maintain myocardial potential to recover during mechanical unloading? 1 Circulation 112:(9 Suppl) I51-I56

Urbanek, K., Torella, D., Sheikh, F., De, Angelis A., Nurzynska, D., Silvestri, F., Beltrami, C. A., Bussani, R., Beltrami, A. P., Quaini, F., Bolli, R., Leri, A., Kajstura, J., and Anversa, P. 14-6-2005 Myocardial regeneration by activation of multipotent cardiac stem cells in ischemic heart failure Proc.Natl.Acad.Sci.U.S.A 102:(24) 8692-8697

Vatta, M., Stetson, S. J., Jimenez, S., Entman, M. L., Noon, G. P., Bowles, N. E., Towbin, J. A., and Torre-Amione, G. 3-3-2004 Molecular normalization of dystrophin in the failing left and right ventricle of patients treated with either pulsatile or continuous flow-type ventricular assist devices J.Am.Coll.Cardiol. 43:(5) 811-817

Weber, C. R., Piacentino, V., III, Ginsburg, K. S., Houser, S. R., and Bers, D. M. 8-2-2002 $\mathrm{Na}(+)-\mathrm{Ca}(2+)$ exchange current and submembrane $[\mathrm{Ca}(2+)]$ during the cardiac action potential Circ.Res. 90:(2) 182-189

Welch, S., Plank, D., Witt, S., Glascock, B., Schaefer, E., Chimenti, S., Andreoli, A. M., Limana, F., Leri, A., Kajstura, J., Anversa, P., and Sussman, M. A. 5-4-2002 Cardiacspecific IGF-1 expression attenuates dilated cardiomyopathy in tropomodulinoverexpressing transgenic mice Circ.Res. 90:(6) 641-648

Wickenden, A. D., Kaprielian, R., Kassiri, Z., Tsoporis, J. N., Tsushima, R., Fishman, G. I., and Backx, P. H. 1998 The role of action potential prolongation and altered intracellular calcium handling in the pathogenesis of heart failure Cardiovasc.Res. 37:(2) 312-323

Wilson, E. M. and Spinale, F. G. 2001 Myocardial remodelling and matrix metalloproteinases in heart failure: turmoil within the interstitium Ann.Med. 33:(9) 623-634

Wohlschlaeger, J., Levkau, B., Brockhoff, G., Schmitz, K. J., von, Winterfeld M., Takeda, A., Takeda, N., Stypmann, J., Vahlhaus, C., Schmid, C., Pomjanski, N., Bocking, A., and Baba, H. A. 2-3-2010 Hemodynamic support by left ventricular assist devices reduces cardiomyocyte DNA content in the failing human heart Circulation 121:(8) 989-996

Wohlschlaeger, J., von, Winterfeld M., Milting, H., El, Banayosy A., Schmitz, K. J., Takeda, A., Takeda, N., Azhari, P., Schmid, C., August, C., Schmid, K. W., and Baba, H. A. 2008 Decreased myocardial chromogranin a expression and colocalization with brain natriuretic peptide during reverse cardiac remodeling after ventricular unloading J.Heart Lung Transplant. 27:(4) 442-449

Woodiwiss, A. J., Tsotetsi, O. J., Sprott, S., Lancaster, E. J., Mela, T., Chung, E. S., Meyer, T. E., and Norton, G. R. 2-1-2001 Reduction in myocardial collagen cross-linking parallels left ventricular dilatation in rat models of systolic chamber dysfunction Circulation 103:(1) 155-160

Xydas, S., Kherani, A. R., Chang, J. S., Klotz, S., Hay, I., Mutrie, C. J., Moss, G. W., Gu, A., Schulman, A. R., Gao, D., Hu, D., Wu, E. X., Wei, C., Oz, M. C., and Wang, J. 2006 
beta(2)-Adrenergic stimulation attenuates left ventricular remodeling, decreases apoptosis, and improves calcium homeostasis in a rodent model of ischemic cardiomyopathy J Pharmacol.Exp Ther. 317:(2) 553-561

Yancy, C. W., Fowler, M. B., Colucci, W. S., Gilbert, E. M., Bristow, M. R., Cohn, J. N., Lukas, M. A., Young, S. T., and Packer, M. 3-5-2001 Race and the response to adrenergic blockade with carvedilol in patients with chronic heart failure N.Engl.J.Med. 344:(18) 1358-1365

Young, J. B. 2001 Healing the heart with ventricular assist device therapy: mechanisms of cardiac recovery Ann.Thorac.Surg. 71:(3 Suppl) S210-S219

Zafeiridis, A., Jeevanandam, V., Houser, S. R., and Margulies, K. B. 18-8-1998 Regression of cellular hypertrophy after left ventricular assist device support 22 Circulation 98:(7) 656-662

Zhang, Q., Xiang, J., Wang, X., Liu, H., Hu, B., Feng, M., and Fu, Q. 2010 Beta(2)adrenoceptor agonist clenbuterol reduces infarct size and myocardial apoptosis after myocardial ischaemia/reperfusion in anaesthetized rats Br.J.Pharmacol. 160:(6) 1561-1572 


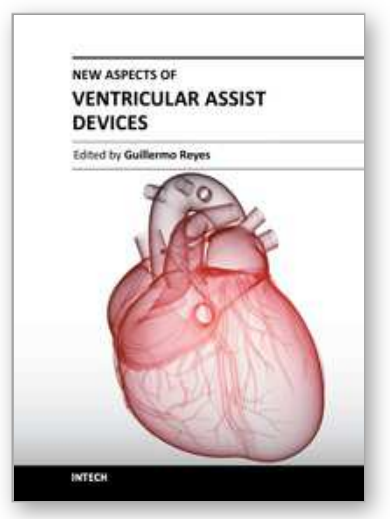

\author{
New Aspects of Ventricular Assist Devices \\ Edited by Dr. Guillermo Reyes
}

ISBN 978-953-307-676-8

Hard cover, 134 pages

Publisher InTech

Published online 29, August, 2011

Published in print edition August, 2011

Ventricular assist device has become one of the standard therapies for the support and the management of the failing heart. Updating our knowledge about these devices is mandatory in order to improve patient outcomes. In this book we can read the efforts made by many physicians concerned with the treatment of heart failure with mechanical devices. We all hope that the information compiled by experts in ventricle assist devices in this book will help us all to do better our main task - heal patients.

\title{
How to reference
}

In order to correctly reference this scholarly work, feel free to copy and paste the following:

M. Navaratnarajah, M. Ibrahim, M. Yacoub and C. Terracciano (2011). Myocardial Recovery Following Left Ventricular Assist Device Therapy, New Aspects of Ventricular Assist Devices, Dr. Guillermo Reyes (Ed.), ISBN: 978-953-307-676-8, InTech, Available from: http://www.intechopen.com/books/new-aspects-ofventricular-assist-devices/myocardial-recovery-following-left-ventricular-assist-device-therapy

\section{INTECH}

open science | open minds

\section{InTech Europe}

University Campus STeP Ri

Slavka Krautzeka 83/A

51000 Rijeka, Croatia

Phone: +385 (51) 770447

Fax: +385 (51) 686166

www.intechopen.com

\section{InTech China}

Unit 405, Office Block, Hotel Equatorial Shanghai

No.65, Yan An Road (West), Shanghai, 200040, China 中国上海市延安西路65号上海国际贵都大饭店办公楼 405 单元

Phone: +86-21-62489820

Fax: $+86-21-62489821$ 
(C) 2011 The Author(s). Licensee IntechOpen. This chapter is distributed under the terms of the Creative Commons Attribution-NonCommercialShareAlike-3.0 License, which permits use, distribution and reproduction for non-commercial purposes, provided the original is properly cited and derivative works building on this content are distributed under the same license. 